\title{
SECURING THE ZAMRUD NATIONAL PARK BASED ON THE TRADITIONAL FISHERMAN COMMUNITY
}

\author{
Hesti Asriwandari, Rina Susanti, Yoskar Kadarisman \\ Departement Sociology, Faculty of Social and Political Sciences, University of Riau \\ E-mail: hesti.asriwandari@lecturer.unri.ac.id; rina.susanti@lecturer.unri.ac.id; yoskar.kadarisman@ \\ lecturer.unri.ac.id
}

\begin{abstract}
The Zamrud Area is designated as a National Park through the Decree of the Minister of Environment and Forestry No. 350/ Menlhk/Setjen/PLA.2/5/2016 Year 2016. Within this area there are two lakes namely Pulau Besar Lake and Bawah Lake and have a diversity of flora and fauna. In the area of the Zamrud National Park, there are fishing communities who have been fishing for generations since the 70s, "mandah" and living in the area, and are involved in guarding and protecting the area from the threat of illegal logging and protected bird catching. The research approach used is qualitative. Research informants were taken based on criteria, namely to obtain a complete picture of the actions of traditional fishermen in securing and protecting the Zamrud National Park. The results showed that the forms of security measures taken by traditional fishermen in preserving the Zamrud National Park were: 1) Conducting river patrols, 2) Disseminating regional regulations, 3) Reprimanding visitors who violated the law, 4) Reporting violations and special incidents to the Forest Police. and BKSDA Riau. In an effort to maintain and maintain the sustainability of fishing activities in the Pulau Besar and Bawah Lake areas, traditional fishermen do: 1) Limit the use of fishing gear, 2) Limit the number and types of catches (not catching fish that are prohibited), 3) Maintain Lakeside Vegetation, 4) Not clearing land and taking forest products in the form of wood, and 5) Cooperating with various parties such as the local government.
\end{abstract}

Keywords: Security; Fishermen; Community; Zamrud

\section{PENGAMANAN TAMAN NASIONAL ZAMRUD BERBASIS KOMUNITAS NELAYAN TRADISIONAL}

\begin{abstract}
ABSTRAK. Kawasan Zamrud ditetapkan sebagai Taman Nasional melalui surat Keputusan Menteri LHK No. 350/Menlhk/ Setjen/PLA.2/5/2016 Tahun 2016. Di dalam kawasan ini terdapat dua danau yakni Danau Pulau Besar dan Bawah Lake serta memiliki keanekaragaman flaura dan fauna. Dalam kawasan Taman Nasional Zamrud terdapat masyarakat nelayan yang secara turun temurun sejaktahun 70-an mencari ikan, "mandah" dan bermukim di kawasan tersebut, serta terlibat menjaga dan melindungi kawasan dari ancaman penebangan liar (illegal logging) dan penangkapan burung dilindungi. Masyarakat nelayan yang bermukim di kawasan Taman Nasional Zamrud berasal dari desa-desa yang berada di sekitar kawasan. Penelitian ini bertujuan untuk mengetahui tindakan yang dilakukan oleh masyarakat nelayan tradisional yang "mandah" bermukim di kawasan Taman Nasional Zamrud dalam menjaga kelestarian lingkungan. Pendekatan penelitian yang dipakai adalah kualitatif. Pengambilan informan penelitian dilakukan berdasarkan kriteria, yaitu untuk memperoleh gambaran utuh tentang tindakan nelayan tradisional dalam mengamankan dan menjaga Taman Nasional Zamrud. Hasil penelitian diperoleh bentuk-bentuk tindakan pengamanan yang dilakukan nelayan tradisional dalam menjaga kelestarian Taman $\mathrm{N}$ asional Zamrud yaitu: 1) Melakukan patroli sungai, 2) Mensosialisasikan aturan kawasan, 3) Menegur pengunjung yang melakukan pelanggaran, 4) Melaporkan pelanggaran dan kejadian khusus kepada Polisi Hutan dan BKSDA Riau. Dalam upaya mempertahankan dan menjaga keberlanjutan kegiatan penangkapan ikan di kawasan Danau Pulau Besar dan Bawah Lake, nelayan tradisional melakukan: 1) Membatasi penggunaan alat tangkap, 2) Membatasi jumlah dan jenis tangkapan (tidak menangkap ikan yang dilarang), 3) Menjaga Vegetasi tepian Danau, 4) Tidak membuka lahan dan mengambil hasil hutan berupa kayu, dan 5) Melakukan kerja sama dengan berbagai pihak seperti pemerintah setempat.
\end{abstract}

Kata kunci: Pengamanan; Nelayan; Komunitas; Zamrud

\section{INTRODUCTION}

Pulau Besar Lake and Bawah Lake are part of the Zamrud National Park which is administratively located in Siak Regency. Zamrud National Park itself ischange the function of the Pulau Besar and Bawah Lake Wildlife Reserve Areas as well as the Serkap Big Lake Permanent Production Forest Area which is legalized through Minister of Environment and Forestry Decree No. 350/Menlhk/Setjen/ PLA.2/5/2016 Year 2016. National Park area. Zamrud has an area $\pm 31,480$ hectares and based on the Long Term Management Plan document, National Park Zamrud is divided into 6 zones, namely the core zone, jungle zone, utilization zone, tradi-tional zone, rehabilitation zone and special zone. The Pulau Besar and Bawah Lake areas belong to the utilization zone. Pulau Besar Lake and Bawah Lake have an area of approximately 2,416 hectares and 360 hectares, respectively (Kadarisman, 2004).

The Zamrud National Park area has the potential for a variety of flora and fauna. Types of 
fluoride that can be found include meranti, ramin, kempas, Bintangur, Nipah and Pandan. While the types of land animals are sun bears, tapirs, Sumatran tigers, deer, long-tailed monkeys, owls, hornbills and monitor lizards. For the lake area, there is abundant potential for fish such as baung, toman, tapah, selais, persuasion, monitor, lompong, catfish, belida, tuakang, mengarik, shrimp and arowana fish. The potential for fishery products in the Pulau Besar and Bawah Lake areas makes this area a the main source of livelihood for a small part of the community who work as traditional fishermen. The fishing communities who catch fish in the lake area generally come from villages around the national park such as Dayun Village, Sungai Rawa, Rawa Mekar Jaya, Lalang Village and Kayu Ara Village. They catch fish using the mandah system or stay temporarily in huts built inside the NP area. Zamrud. The results of interviews with the head of the Zamrud fishermen group, in 2020, there were a total of 28 traditional fishermen looking for fish and living in the National Park area Zamrud. This number has increased compared to 2017 with details:

Table 1. Number of Fishermen Seeking Fish and Settling in Zamrud National Park

\begin{tabular}{ccc}
\hline No. & Year & $\begin{array}{c}\text { Fishermen } \\
\text { (Poeple) }\end{array}$ \\
\hline 1 & 2015 & 23 \\
2 & 2017 & 27 \\
3 & 2019 & 28 \\
\hline
\end{tabular}

Source: Chairman of the Zamrud Fishermen Group, 2020

Fishing activities in the area Pulau Besar Lake and Bawah Lake have been going on before 1975. This means that long before this area was designated as a Wildlife Refuge which later changed its status to a National Park, traditional fishing communities existed in the area. However, no official information was found on the number of fishermen before 1975. Report on SEL Study of Zamrud Oil Field Development (1985) It is estimated that in 1975 there were 5 traditional fishing families who settled and looked for fish in Big Island Lake and Bawah Lake (Amanah, 2010).

The existence of fishing communities in the National Park. Zamrud is not a threat to the regional ecosystem, as perceived by some. Their presence actually helps save and preserve the National Park area. Zamrud. In the view of environmental ethics, it is stated that there is a relationship between humans and nature. Where humans are an inseparable part of nature, and the development of human life is integrated with theevolutionary process and the development of life in the universe as a whole (Keraf, 2010). To be able to exist, survive, live as a creature that has intelligent thoughts, namely humans in the broadest and fullest sense, humans depend on nature and not only on fellow humans. That is the view of the traditional fishing community towards the National Park area Zamrud who considers the act of preserving the area of the lake and Zamrud forest is important. This is because fishermen are aware that their source of livelihood comes from nature and nature needs to be maintained so that they can always provide results for humans.

Defining the concept of fishermen requires a broad overview and perspective, whether based on residence or employment status. Fishermen are often defined as people who carry out fishing activities in the sea (Satria, 2015, p. 26). Or a community group that uses the sea as a source of livelihood, either by fishing or cultivating it. Fishermen usually live and settle in a residential area close to the work area, namely on the edge of the beach (Imron, 2001).

In coastal communities, traditional fishermen are the most vulnerable, suffering and poor groups. In general, traditional fishermen are defined as individual individuals who carry out fishing work using simple means of transportation with fishing equipment. As implied by law (Law No. 31/2004), traditional fishermen are fishermen whose fleets are less than 5 GT or under $15 \mathrm{PK}$ and free from various levies and business license obligations (Satria, 2009). Due to the limited engine power of boats and fishing gear, the fishing area is limited. These traditional fishermen are usually fishermen who are regenerating fishing activities to make ends meet.

The dependence of traditional fishermen on nature and the season is very high, as a result fishermen cannot go down to find fish all the time, especially during the north wind season. Apart from limited catches, in certain seasons traditional fishermen cannot even produce fish due to limited technology and fishing gear. This condition makes traditional fishermen unable to escape poverty. The low fishing technology and the high dependence of traditional fishermen on natural products, cause them to always maintain a relationship with nature, especially for traditional fishermen who catch fish in rivers or lakes. To be related means that everything in the universe is linked like a chain that complements and needs one another (Keraf, 2010; Sidiq, Maulida, H \& Achmad, 2021). Therefore, to be able to catch fish, traditional fishing communities play a role in protecting nature and the environment.

The concept of community participation hasa broad meaning and meaning, in this study it is associated with participation. Some experts and practitioners explain participation as something 
which basically rests on attitudes, behaviors and actions even though the boundaries are vague, but can be easily explored and implemented but are quite difficult to describe and formulate. The role of society or participation can be translated as the conscious participation of individuals in an activity or social interaction in certain environmental conditions (Sofro, at.al, 2021).

While Isbandi defines community participation as an effort to involve individuals or groups in an effort to identify disturbances and forces that exist in society, filter decisions about alternative problem solutions, implement efforts to solve problems, and community participation in evaluating changes that occur. (Rukminto, 2007). The most important aspect of community participation is a multi-party collaboration which is based on the principles of trust and transparency from the community itself (Sidiq \& Achmad, 2020). Community participation can be carried out individually or in groups. In the form of groups or communities, individual involvement in social interactions tends to be stronger and more effective. These community groups can be based on area units, livelihoods, and customs (Sidiq, 2020).

Participation or participation will not be effective if it is only to promote the desire and willingness of the community without being given the opportunity by the government (along with guarantees of protection), of course this condition can more or less bring legal effects related to whether development and environmental preservation efforts, for example. On the other hand, the policies and programs launched by the government will find it difficult to run optimally if the people do not have the will and ability. Thus things that are interpreted as the participation or participation of the community will not be realized. The estuary of the development stage is to position the prosperity of the community as the subject and its central object. it is imperative for government administrators at both lower and upper levels to involve the community in development activities in order to achieve common goals by opening the widest possible opportunity for the community to actively participate. Of course, no one better understands and understands the meaning of the prosperity and welfare of society than the community itself.

According to Conyers, there are 3 (three) central explanations for why participation has a fundamental character (Conyers, 1991; Rahman, 2019), including First community participation as a vehicle for obtaining data and information regarding the situation, community behavior and local communities. Interests that are not present in a development activity are likely to experience disappointment and failure.

Second, the community will put their trust in a development program, if they are involved in every stage of the activity starting from the preparation and planning stage, thus the community will have more control over the ins and outs of these activities and can foster a sense of responsibility and belonging to these activities.

Third, symbolizes the right to democracy when the community is included in the stage of community development itself. Participation from the government's point of view is to run and implement something at the lowest possible cost, and generate various interests with limited and minimal funds.

The involvement of individuals contributing to groups is not the same between community members and communities. This correlates with the physical competence, knowledge, education and skills, stimuli and interests of the individual. Keith Davis inside (Sastropoetro, 1988; Handoko, 2017) explain forms of community participation including: ideas, personnel, expertise, equipment and funding (money).

Traditional service communities in the Zamrud National Park area generally have a low educational background and income but have a high willingness to maintain and maintain the character and quality of the biological environment and the national park area. This is driven by: (ICEL, 2009; Amanah \& farmayanti, 2014) (1) The existence of community relations with the national park area; (2) There is a need factor, both from a historical and social background-religion, cosmos and economy of local communities; (3) There is concern and commitment (as is done by environmental NGOs and communities of rescue and lovers).

Placing the community as the subject of preservation and development of the national park area is absolutely necessary, so that the community will be motivated to actively participate in the development and preservation of forest areas. The form of participation of traditional fishing communities in the development of forest areas can be in the form of safeguarding and safeguarding forest area ecosystems and maintaining the sustainability of fishing activities in the lake area.

Forest area security is an effort to stem and limit disturbance to forest areas and forest products, caused by human (community) actions, livestock, fire, pests and diseases as well as defending and maintaining the rights of the state, community and individuals to the forest. (Siregar, 2014). Forest area security activities can be carried out by: (1) 
Preemptive activities, namely the act of providing consultation to forest area managers about threats and problems that occur in order to establish a supportive and conducive situation. (2) Preventive activity, namely an action aimed at preventing disasters from occurring in the security and preservation of forest area ecosystems. (3) Repressive activities, namely coping actions against parties that have made threats to forest areas, countermeasures in an effort to strengthen the law and restore.

Threats to the sustainability and ecosystem of Zamrud National Park actually originate from the areas of Forest Control Rights (HPH), Industrial Plantation Forests (HTI) and oil palm plantations owned by several large companies which are directly adjacent to National Park Zamrud, especially in the north and west of the area. Other threats that are thought to disrupt the Zamrud ecosystem are illegal logging, illegal fishing and illegal fishing, land grabbing because part of the area borders community plantations, clearing accessibility and burning land.

The increasing status of the Zamrud area to a National Park has made the pressure on the ecosystem of the area has recently increased. Moreover, this area is part of the Pekanbaru Coastal Plain Block area. The 2010 data shows that in the Zamrud area there are about 122 oil which is exploited by the Siak Regency Government through Joint Operation Agency (BOB) of PT. Bumi Siak Pusako - Pertamina Hulu. Economic development activities spurred by regional autonomy and central policies around the Zamrud National Park area, are expected to have an impact on the sustainability and characteristics of the Zamrud ecosystem.

In order to ensure the functioning of the Zamrud National Park ecosystem runs well for the environment as a whole and is protected from the various threats mentioned earlier, it is necessary to conserve, protect and protect the Zamrud area. For this reason, it is necessary to conduct research on the role of the community, especially the Zamrud traditional fishing community in protecting and preserving the national park area. The purpose of this study was to determine the role or forms of security measures taken by traditional fishermen in preserving the park. Zamrud and efforts to maintain the sustainability of fishing activities in the Pulau Besar and Bawah Lake areas.

\section{METHODS}

This study uses a qualitative approach with a descriptive method which aims to describe the meaning of a group of fishermen living in the Zamrud
National Park area. The research location is in the Zamrud National Park, Siak Regency. Furthermore, to obtain complete information regarding the actions of traditional fishermen in securing and protecting the Zamrud National Park, research informants were selected based on specific objectives. Determination of researchsubjects usingpurposivesamplingmethod, in which the research subjects are selected carefully so that they fit the research structure (Semiawan, 2010; Asriwandari et al, 2017). Research subjects were selected based on predetermined parameters in accordance with the research objectives. Infomans or subjects in this study are traditional fishermen who have huts and live in the National Park Zamrud area and members of the Riau BKSDA.

\section{RESULTS AND DISCUSSION}

Zamrud National Park is administratively located in Dayun Village, Siak Regency, with a distance of approximately $180 \mathrm{Km}$ from the center of Pekanbaru City and is the 3rd (third) national park owned by Riau Province. Zamrud National Park is change the functions of the Pulau Besar and Bawah Lake Wild life Areas as well as the Serkap Large Permanent Production Forest Area, the stipulations of which are stipulated in Decree of the Minister of Environment and Forestry No. 350/Menlhk/Setjen/ PLA.2 / 5/2016 Year 2016.

National Park Zamrud is a primary swamp forest, which geographically, the soil layer is like a giant basin which is a gathering place for water from the surrounding areas. Zamrud National Park has an area $\pm 31,480$ hectares and $100 \%$ of the area is peat soil with a depth of up to \pm 6 meters.

Zamrud area is a combination of two adjacent lakes Pulau Besar Lake with an area of 2,416 hectares and Bawah Lake of 360 hectares. The name Pulau Besar Lake is taken from the four islands in the lake, namely Besar Island (10 ha), Tengah Island (1 ha), Bungsu Island (1 ha) and Beruk Island (2 ha). It is named Beruk Island because the island is inhabited by a group of monkeys. The fourth This is one of the uniqueness of the Zamrud National Park. The conditions float on the lake and can move during the monsoons because the island's bottom does not take root.

Another uniqueness and beauty of National Park Zamrud is dark lake and swamp water in this area. When the sun begins to set, the color of the lake will turn black like an Zamrud. In addition, there are various types of animals in this area, including: (1) fish, there are 14 types of fish; (2) birds, there are 38 species; (3) large mammals, Sumatran tigers, tapirs, sun bears, black cats; (4) primates, there are 4 types. 


\section{Traditional Fishermen Community in Zamrud National Park Area}

Fishing activities in the Zamrud National Park area, to be exact, in Pulau Besar Lake and Bawah Lake have been going on for several generations. fishing activity is only a side activity by the majority of the population during the fishing season. However, there is also a small part of the community who make it their main source of life. This community group is known as mandah traditional fishermen or fishing communities who live and settle in the Zamrud area for a while (maximum 3 weeks).

No official information was found regarding the number of traditional fishermen who were fishing in the lake area before 1975. However, in the report of the SEL Study on Zamrud Oil Field Development (1985) it is stated, it is estimated that before 1975 there were 5 fishing families living in Danau Besar Island and Bawah Lake. This number increased to around 18 fishermen between 1975-1980, and 41 fishermen in 1984.

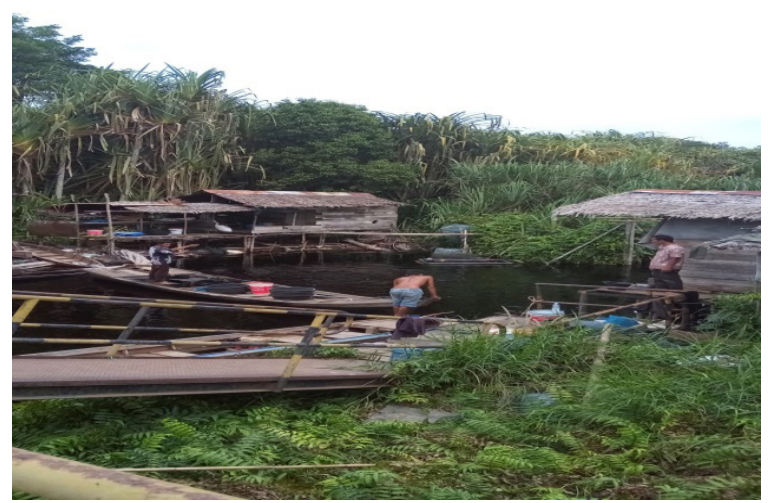

Figure 1. Traditional Fishermen's Houses in the Big Island Lake Stream

At the time of this research (in 2019), there were 28 traditional fisher men who live in the lake area, 17 of them are in Pulau Besar Lake and 11 other fishermen are in Bawah Lake. Fishermen who live in the entire lake area are of Malay ethnicity and come from villages around the National Park, namely from Dayun Village, Sungai Rawa, Rawa Mekar Jaya, Kayu Ara Village and Lalang Village. Detailed in the following table 2 .

People looking for fish in the National Park area. Zamrud is not only those who live in the area but there are also people who do not live (from Dayun village, Sungai Rawa and Desa Rawa Mekar Jaya) who are also involved in fishing in the lake area. However, the nature of this group of fish finders is only seasonal, meaning that they are only looking for fish only as a hobby or when there are many fishing seasons. The results of the field interviews show that there are \pm 20 seasonal fish hunters in the big lake and small lake villages.
Table 2. Names of Fishermen Residing in Zamrud National Park in 2019

\begin{tabular}{|c|c|c|c|}
\hline No. & Fisherman Name & Gender & Origin Village \\
\hline 1 & Abdul Muis & $\mathrm{L}$ & Kampung Rawa \\
\hline 2 & Sutris & $\mathrm{L}$ & Kampung Rawa \\
\hline 3 & Sarin & $\mathrm{L}$ & Kampung Rawa \\
\hline 4 & Musli & $\mathrm{L}$ & Kampung Rawa \\
\hline 5 & Ridwan & $\mathrm{L}$ & Kampung Rawa \\
\hline 6 & Mujianto & $\mathrm{L}$ & Kampung Rawa \\
\hline 7 & Mesran & $\mathrm{L}$ & Kampung Rawa \\
\hline 8 & Ari & $\mathrm{L}$ & Kampung Rawa \\
\hline 9 & Sun & $\mathrm{L}$ & Kampung Rawa \\
\hline 10 & Indra & $\mathrm{L}$ & Kampung Rawa \\
\hline 11 & Mahmud & $\mathrm{L}$ & Dayun \\
\hline 12 & Services & $\mathrm{L}$ & Dayun \\
\hline 13 & Services Hasri & $\mathrm{L}$ & Dayun \\
\hline 14 & Carsini & $\mathrm{P}$ & Dayun \\
\hline 15 & Zum & $\mathrm{L}$ & Dayun \\
\hline 16 & Buyung & $\mathrm{L}$ & Dayun \\
\hline 17 & Very & $\mathrm{L}$ & Dayun \\
\hline 18 & Warsino & $\mathrm{L}$ & Dayun \\
\hline 19 & Jupri & $\mathrm{L}$ & Dayun \\
\hline 20 & Adani & $\mathrm{L}$ & Dayun \\
\hline 21 & Indra Gunawan & $\mathrm{L}$ & Dayun \\
\hline 22 & Dervish & $\mathrm{L}$ & Rawa Mekar Jaya \\
\hline 23 & Rizuan & $\mathrm{L}$ & Rawa Mekar Jaya \\
\hline 24 & Mardi & $\mathrm{L}$ & Rawa Mekar Jaya \\
\hline 25 & Jumin & $\mathrm{L}$ & Rawa Mekar Jaya \\
\hline 26 & Amen & $\mathrm{L}$ & Rawa Mekar Jaya \\
\hline 27 & Jalil & $\mathrm{L}$ & Lalang \\
\hline 28 & Jul & $\mathrm{L}$ & Kayu Ara \\
\hline
\end{tabular}

Source: Head of the Zamrud Nelayam Group, 2020

The traditional fishermen groups who live in the Zamrud area are only temporary (mandah). In one month, fishermen usually stay for \pm 23 days in the area and \pm 7 days in the village gathering with their families. To reach the lake area, there are 2 (two) routes commonly used by fishermen, namely the land route (through the road belonging to PT. BOB BSP) and the river swamp route-Zamrud lake. Traditional fishermen who come from Dayun Village generally use the road access to the lake area with a travel time of approximately 40 minutes from the village. Meanwhile, fishermen who come from the village Rawa River, Rawa Mekar Jaya, Kayu Ara and Lalang Village use the access route from the swamp river - Zamrud lake with a travel time of approximately 3 hours will be pompong and canoe.

In marketing activities, fish caught by fishermen are generally sold directly to collectors. This way, the container picks up the fishermen's catch to the lake. Within 1 (one) week, this container will enter 2-3 times into the lake area to buy the fishermen's catch. Apart from being sold directly, there are also some fishermen who process their catch by making smoked fish (smoked fish).

There are 2 (two) collectors who usually buy the catch of Zamrud traditional fishermen with varying 
selling prices. Types of fish with high economic prices include toman fish, selais, baung, tapah and shrimp.

\section{Actions of Traditional Fishermen in Safeguarding the Zamrud National Park Area}

The activities of securing the National Park area carried out by traditional fishing communities are a form of participation in forestry conservation and development. Participating means contributing to an activity or development (Iskandar, 2013). The practice of participation or involvement of fishermen in security activities has been carried out for a long time, even before this area was designated as a Wildlife Reserve Area which later turned into a national park. Forms of security measures include: socialization of area rules, admonishing visitors, river patrols and reporting violations and special incidents to related parties. The nature of the security that is carried out includes issues of conservation, preservation of the area and sustainability of the fishermen's fishing business it self.

\section{Area Socialization}

One of the efforts to preserve the Zamrud National Park ecosystem is by disseminating regional regulations to the wider community. The more information is spread about an area, the better the understanding of individuals or communities about what is prohibited, allowed and sanctions and the less likely it is to violate. Traditional fishing communities who live in the Zamrud lake area also play an active role in socializing and disseminating forestry information and regulations on the NP area. Zamrud as a form of security measures for forest areas. The socialization was not only provided by fishermen to village communities but also to NP visitors. Zamrud (Wiratama et al, 2014; Mulyadi, 2019)

As a member of the community who has direct contact with the Zamrud area, these traditional fishermen are quicker to obtain information regarding forestry and regional regulations from related parties. And the information they received they helped to distribute to other communities in the village, including visitors to the National Park area Zamrud encountered. For visitors, usually fishermen will inform them about the prohibition on taking forest products, the prohibition on fishing protected in the lake area, the prohibition not to throw cigarette stems carelessly and informing the types of wild animals found in the Zamrud area.

\section{Reprimanding Visitors}

The Zamrud National Park area is wide open for people who want to go on a recreation, learn about nature conservation and the environment, and the village community around the area is no exception. The impact is National Park Zamrud is increasingly depressed by the presence of visitors. As people who live in the Zamrud forest area, traditional fishermen play a role in supervising and securing the National Park. Zamrud from the threat of this visitor. The security measures they usually take are admonish visitors who carry out prohibited activities in the area, such as reprimanding visitors who throw cigarette butts carelessly, starting a fire in the area and littering. threatens the sustainability of the Zamrud area.

"There are also many visitors who enter the forest and lake areas, not only villagers around the forest area but also outside people who want to have recreation and study like students. We often reprimand visitors for acting threatening the area. For example, they smoke and throw cigarette butts carelessly, we are immediately reprimanded for fear that it will cause a fire. Likewise, those who make litter, we just admonish it. Yes .. for the security and sustainability of the forest area " (Informant Interview 2, 2020)

This action is a manifestation of the fishermen's commitment to preserving the forest area in a very simple form but has a significant contribution. The view of fishermen, humans as an integral part of nature, behavior full of responsibility, full of respect is necessary for the continuity of all life in the universe (Keraf, 2010; Vibriyanti, 2016)

\section{Forest and River Area Patrol}

Patrol is an activity of supervising an area which is the task and responsibility of a personal or group carried out by tracing, moving from one point to another in the forest area(Siregar, 2014, p. 13). Or to regularly and periodically supervise an area (forest area) that is detected as prone to or where there are frequent threats and disturbances to the sustainability of the forest. The purpose of conducting patrol activities is to reduce the space for violations to occur and is usually carried out by law enforcement officials. In the Zamrud National Park area, patrol activities are not only carried out by law enforcers (forest police) but also involve traditional fishing communities (Hoskins, 2002). The fishing communities who live in the Zamrud forest area usually carry out patrol actions (in the form of perondaan) independently, namely simultaneously with their mobility in the lake area and swamp river flow. When fishermen take a trip along the swamp river flow which becomes the access to the waterway 
to the lake area, They not only crossed the route but also made occasional observations and checks at a location that seemed to be changing regularly. And when they find a disturbance, fishermen immediately report it to the relevant parties (Forest Police and BKSDA).

As a community who has hereditary looking for fish and living in the lake area, fishermen really understand the ins and outs of the Zamrud forest area. This understanding becomes the capital for them to participate in patrol activities and preserve the ecosystem of forest areas. Because one of the requirements to become a patrol officer is control of the area of duty.

\section{Reporting Violations and Special Events}

The role of traditional fishermen in securing and preserving the ecosystem of other areas is to provide information to related parties (such as: Forest Rangers, BKSDA, BRG Facilitators and BOB BSP companies regarding the existence of people suspected of damaging the National Park area, notifying the theft of forest products, informing the sources of the problem and informing or reporting specific incidents in the form of land fires that have occurred in national park zones, especially at oil well operations andaccess road of PT. Bumi Siak Pusako. This security measure carried out by traditional fishermen is a form of participation in a very simple form but has an important meaning given the large area of the Zamrud National Park area and the limited number of rangers and members of the BKSDA.

The security measures taken by traditional fishermen have not yet reached the stage of handling the problem which is informed either individually or collectively, except to help extinguish burning land with makeshift tools. Or reprimand the public for committing minor offenses. Traditional fishermen do not want to take risks too far because the obligation to solve problems is the responsibility of the Forest Police, BKSDA and the BOB company.

\section{Traditional Fishermen's Efforts to Maintain Fishing Business Sustainability}

The life of traditional fishermen who live in the Zamrud forest area is very dependent on natural products. Because their only source of income comes from fishery potential in the lake area (Cahyadi, 2016). As a community who completely depend on the lake area through fishing activities, there are several efforts made by traditional fishermen so that the sustainability of fishing in the Zamrud lake area can last for a long time.present and future generations, including:

\section{Limiting Use of Fishing Tools}

In fishing business in the Zamrud lake area, fishermen still use simple technology such as traps, lukah, nets, longline fishing rods, pengilar and tambat. On average, the equipment used by fishermen is still made of natural materials from nature such as bamboo, wood and rattan so that it does not have the potential to cause damage. Even some of them are environmentally friendly, such as traps/lukah and pengilar because the fish caught are still alive, so if the fish caught is a protected species or has no economic value, it will be released back by the fishermen.

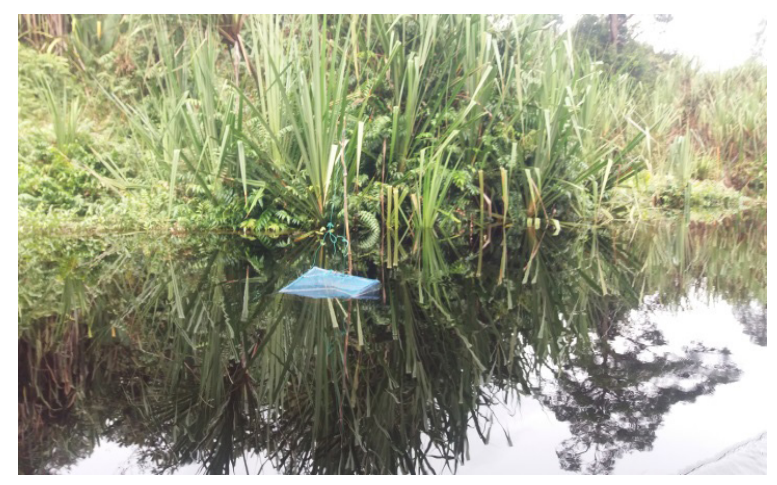

Figure 2. Traditional fishing gear

Apart from using simple technology, traditional fishermen in the Zamrud lake area also limit fishing gear operations. The goal is to maintain the natural regeneration process of fish and maintain the sustainability of fishermen's business in the lake area. On average, each individual fisherman has various types of fishing gear. The number of each type of fishing gear varies, the most fishermen have are types of lukah, traps and pengilar. Generally, fishermen have 15 units of traps and pengilar.

Basically, the Riau Province Natural Resources Conservation Agency does not limit the number of fishing gear each fisherman has, but only records them. It is the awareness of the importance of preserving and establishing relationships with nature that makes fishermen survive with simple technology amid the development of various modern fishing gear technologies.

\section{Limiting the Number and Types of Catched Fish}

In maintaining the sustainability of the capture fisheries business in the Zamrud lake area, traditional fishermen agree not to exploit or over-fish. The goal is that nature can always provide benefits for both the present and future masses. Fishermen's commitment to limiting the amount of catch is in line with the number and type of fishing gear used, which is limited and environmentally friendly. The orientation of fishermen's work also does not lead to the level 
of economic stability but only for survival, which means that fishing efforts carried out by fishermen are not forced to collect fish as many as you can every day without thinking about the future.

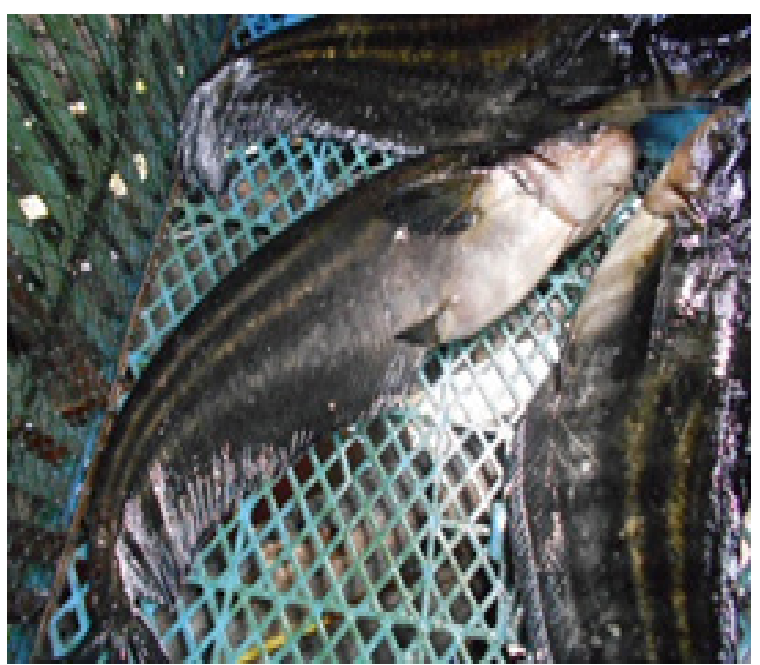

Figure 3. Fish from the Catch of Fishermen

There is fishermen's ethics in fishing activities, namely not catching small fish or those categorized as fry and broodfish. This is done so that the fish population in the lake area can be maintained by providing opportunities for fish to regenerate naturally. Apart from limiting the amount of catch, traditional fishermen in the Zamrud area also limit the types of fish caught. The category of fish caught by fishermen is fish that have economic value, such as shrimp, toman, baung, selais, persuasion and inert.

In the Zamrud lake area, there are arowana fish with very high economic value, but this type of fish is not the object of fishermen's catch. Because fishermen understand that arowana fish are protected fish and must be preserved. When fishermen accidentally catch arowana fish, they will release it again. Likewise, types of fish with low economic value, if fishermen catch this fish in large numbers then they will take enough for family consumption needs and the rest they return to nature.

\section{Maintaining the lakeside vegetation and cleaning the lake area}

Maintaining vegetation on the banks of the lake and river flow has long been practiced by traditional fishermen, namely by not cutting down trees that can damage the environmental ecosystems of Pulau Besar and Bawah Lakes. Traditional fishing communities in the Zamrud area depend heavily on the natural products of the lake area. Because fishermen are aware, it is important to preserve the Zamrud forest ecosystem so that nature can always provide and provide results to fishermen. The fishing community understands well, if the forest is cut down, especially the trees that grow on the edge of the lake, on the one hand it will have an impact on the flow and discharge of water which is increasingly unstoppable and can cause flooding. On the other hand, the fish that usually nest in tree roots will also be disturbed and migrate if their ecosystem is disturbed.

Apart from not cutting trees, traditional fishing communities who live in forest areas also do not litter the household waste they produce carelessly. The results of the interview, fishermen stated that the household waste they produce was brought back to the village so that it would not pollute the lake and forest areas. In maintaining the preservation of lakes and forests, fishermen in the Zamrud area also clean the lake from the thickets that grow thickly blocking the water flow of Pulau Besar and Bawah Lakes. The goal is to control lake water discharge and fishermen's fishing efforts to continue.

\section{Not Clearing Land and Taking Forest Products}

Living from forest areas does not cause traditional fishing communities to act arbitrarily to take advantage of forest and lake products. Even though they have lived for a long time in the Zamrud forest area, fishermen still maintain ethics not to clear land and take forest products carelessly. Although sometimes fishermen need wood and planks to provide fishing gear such as needing wood to repair boats, make fishing gear or repair huts. Fishermen are still trying to find or buy wood from the village or if they are in urgent need of timber, fishermen will first report to the BKSDA and if allowed they will choose wood from dead trees.

Traditional fishermen who live in the Zamrud forest area do not only act as consumers but also as producers. In this case they do not only take the products of the lake but also play a role in protecting their area. Zamrud traditional fishermen who have been for generations to look for fish in the lake area have never exploited forest products, let alone trying to open forest land for gardening. Because fishermen believe that when they take this action, the catch business which is their source of livelihood will be threatened in the future.

\section{CONCLUSION}

Based on the results of the research that has been carried out, it can be concluded several things with regard to security Zamrud National Park is based on a traditional fishing community namely as follows: Traditional fishing communities who live in the Zamrud National Park area are Malay people who come from villages around the National Park, namely from Dayun Village, Sungai Rawa Village, 
Rawa Mekar Jaya Village, Lalang Village and Kayu Ara Village. The fishing activity in the Pulau Besar and Bawah Lake areas is the main source of livelihood for fishermen which has been carried out from generation to generation. The forms of security measures taken by traditional fishermen in an effort to conserve the Zamrud forest ecosystem are in the form of socializing area regulations, reprimanding visitors, patrolling rivers and reporting violations and special incidents to related parties. Efforts made Traditional Fishermen in Maintaining the Sustainability of Catching Fish, namely: 1) Limiting the Use of Fishing Tools, 2) Limiting the Number and Types of Catched Fish, 3) Maintain Vegetation on the banks of the Lake and Clean the Lake Area, 4) Not Clearing Land and Taking Forest Products

\section{REFERENCES}

Amanah, S. (2010). Peran komunikasi pembangunan dalam pemberdayaan masyarakat pesisir. Jurnal Komunikasi Pembangunan, 8, (1). 1-19

Amanah, S. \& Farmayanti, N. (2014). Pemberdayaan sosial petani-nelayan, keunikan agroekosistem, dan daya saing. Jakarta: Yayasan Pustaka Obor Indonesia.

Asriwandari, H., Meilani, N. L., \& Sadad, A. (2017). Institutional Development of Rubber Farmers in the Implementation of Social Capital. Applied Science and Technology, 1, (1), 516-520.

Cahyadi, R. (2016). Nelayan dan Pertarungan terhadap Sumber Daya Laut. Jurnal Kependudukan Indonesia, 7(2), 127-144.

Conyers, D. (1991). Social Planning in the Third World. Yogyakarta: UGM Press.

Handoko, W. (2017). Menjaga Sustainabilitas Pengembangan Masyarakat Pesisir Kebumen: Antara Corak Top-Down, Partisipatif dan Inisiasi Kelembagaan Lokal. Sosiohumaniora, 19, (3), 244-252.

ICEL, IC (2009). Review of Laws and Policies for Conservation Area Management in Indonesia Towards Development of Decentralization and Increased Community Participation. Bogor: ICEL.

Imron, M. (2001). Fishermen Community Empowerment. Yogyakarta: Media Pressindo.

Iskandar, D. (2013). Daya Tangkap Bubu Lipat Yang Dioperasikan Oleh Nelayan Tradisional Di Desa Mayangan Kabupaten Subang Saintek Perikanan: Indonesian Journal of Fisheries Science and Technology, 8, (2), 1-5.

Securing the Zamrud National Park Based on the Traditional Fisherman Community in Besar Lake Area and Lake Below Siak District (Hesti Asriwandari, Rina Susanti, and Yoskar Kadarisman)
Kadarisman, Y. (2004). Community Participation in Maintaining the Wildlife Reserves (KSM) of Pulau Besar and Danau Bawah Danau Zamrud in Siak Regency. Journal of Society and Culture. 3, (1),

Keraf, US. (2010). Environmental Ethics. Jakarta: PT. Kompas Media Nusantara.

Khadiyanto, P. (2007). Community Participation in the Construction of New School Units. Semarang: Diponegoro University Publishing Agency.

Mulyadi. (2007). Marine Economics. Jakarta: PT Raja Grafindo Persada.

Mulyadi, A. (2019). Modeling of tourists, local population, natural and cultural resources toward ecotourism product (case study in Seagrass Trikora Conservation Area). Society and Business Review. 15, (1), 1-20

Rukminto, AI (2007). Community Asset-Based Participatory Planning: From Thinking to Application. Jakarta: FISIP UI Press.

Rahman,Z.(2019). Perlindungan Dan Pemberdayaan Nelayan. Jurnal Rechts Vinding Media Pembinaan Hukum dan Nasional, 25, 1-5. Https://rechtsvinding.bphn.go.id/jurnal_ online

Sastropoetro, S. (1988). Participation, Communilation, Persuasion and Discipline in National Development. Bandung.

Satria, A. (2009). Fisherman Political Ecology. Yogyakarta: LKis.

Satria, A. (2015). Introduction to the Sociology of Coastal Communities. Jakarta: Indonesian Torch Foundation.

Siregar, P.G, (2014). Community Based Forest Safeguard Guidelines. Jakarta: FORINA.

Sidiq, R.S.S., Jalil, A. \& Achmad, R. (2021). Virtual World Solidarity: How Social Solidarity is Built on the Crowdfunding Platform Kitabisa.com. 18, (1), 192-202. https://doi. org/10.14704/WEB/V18I1/WEB18083

Sidiq, R.S.S, Maulida, H. \& Achmad, R. (2021). Exploring Health Disparities in Indigenous Akit Tribal Community in Riau Province. 37, (1), 1-10.

Sidiq, R.S.S. (2020). Strategy Coastal Community Panglima Raja Village. Sosiohumaniora, 22, (3), 281-288. https://doi.org/10.24198/ sosiohumaniora.v22i3.27728 
Sidiq, R.S.S. \& Achmad, R. W. W. (2020). Gender aspects in remote indigenous community empowerment program in Indonesia. Journal of Advanced Research in Dynamical and Control Systems, 12(6), 2104-2109. https:// doi.org/10.5373/JARDCS/V12I6/S20201172
Vibriyanti, D. (2016). Kondisi sosial ekonomi dan pemberdayaan nelayan tangkap kota Tegal, Jawa Tengah. Jurnal Kependudukan Indonesia, 9,(1), 45-58. 